\title{
中国成都市における街路の利便性評価に対する適応的指示モデルの応用
}

\author{
万 可*, 楊 鶤**, 李 力*, 南 弘征 ${ }^{* * *}$, 下川 敏雄 ${ }^{* * * *}$, 水田 正弘*** \\ * 北海道大学大学院, ${ }^{* *}$ 西南交通大学, ${ }^{* * *}$ 北海道大学情報基盤センター, $* * * *$ 和歌山県立医科大学大学院
}

\section{Application of Adaptive Index Model to Evaluate Streetscape Convenience Evaluation Survey Data in Chengdu}

\author{
Ke WAN*, Kun YAN**, Li LI**, Hiroyuki MINAMI***, Toshio SHIMOKAWA**** and Masahiro MIZUTA*** \\ * Graduate School of Informatics Science and Technology, Hokkaido University, Kita 14, Nishi 9, Kita-ku, Sapporo, Hokkaido 060-0814, Japan \\ ** Southwest Jiaotong University, Chengdu 610031, Sichuan, China \\ *** Hokkaido University Information Innovative Center, Hokkaido University, Kita 11, Nishi 5, Kita-ku, Sapporo, Hokkaido 060-0814, Japan \\ **** Graduate School of Medicine, Wakayama Medical University, 811-1 Kimiidera, Wakayama, Wakayama 641-8509, Japan
}

\begin{abstract}
China has become the world's second largest economy after recent rapid economic growth. On the other hand, the urbanization of China has aggravating the problems of air pollution, traffic congestion, and the dual structure of urban and rural areas. Therefore, the Chinese government has implementing a policy to revise the efficiency-oriented city planning to the quality-oriented, namely "National new urbanization plan". We conducted a questionnaire survey on streetscapes in Chengdu, China. In this survey, we asked pedestrians and bicycle users about the streetscape during traffic. We applied AIM (Adaptive Index Model) method [1] to analyze this survey data. We used the estimated AIM results to score the satisfaction of the streetscape based on "production rules". As a result, safety was important for each traffic, and street cleanliness and the number of bicycle parking lot was important for cyclists. Moreover, Satisfaction was low in the school district and the vicinity of parks. On the other hand, the streets were highly satisfied in the shopping district.
\end{abstract}

Keywords : Questionnaire survey, Adaptive index model, Production rule

\section{1. 序}

中国は，近年の急激な経済成長を経て，世界第2位の経済 大国になった。とくに，1978年12月に開催された中国共産 党第 11 期中央委員会第 3 回全体会議で打ち出された「改革 開放政策」が端をなす, 政策転換は, 大都市の更なる都市化 と農村部から大都市への民衆の流入をもたらした。これらの 大幅な人口の増加と発展に応えるため, 各都市の開発は, 高機能・高効率 (効率重視) に重点がおかれてきた.

一方で，中国の都市化は，大気污染，交通渋滞，都市と 農村の二元構造問題を深刻化させている. 効率重視の都市 計画を改めるために, 2014年3月に, 中国国務院から「国家 新型都市化計画」が交付された [注 1]. そのような時流のな か, 中国の都市開発は, 量から質に重点が移行しつつある. 富田 [2] は, 中国の都市開発が「グリーン」,「スマート」, 「人文 (文化・歴史)」といったテーマを揭げたまちづくりが 活発に行われていくことを示唆している.

「質」を重視した都市計画において, 街路が果たす役割は 大きいように思われる。 そのため, 本論文では中国の街路に 対する利便性の評価に焦点を当てる. 調査地点には, 中国の 主要都市のなかでも，先進的に「質」を重視した都市計画を 志向している四川省 成都市を選定した。 そして, 街路を通行す る被験者に対して，利用中の街路の利便性に対する満足度と ともに街路および周辺環境に関するアンケート調査を実施した。
このとき，街路をアクセスする方法には，徒歩，自転車あるい は電気自転車 [注2] が考えられる。街路の利便性に関する 満足・不満足 (以下, 満足度)には，それぞれのアクセス方法に よって異なることが予想される，そのため，徒歩および自転車 利用者に対して, 異なるアンケート項目での調査を行った。

本論文の目的は, アンケート調査を通じて, 街路の利便性 に対して影響を及ぼす物理的な要因を評価することにある. このとき, 以下の 3 点の目標を掲げる：(1) 満足度に影響を 及ぼす要因（影響要因）を評価すること，（2）影響要因をどの 程度評価すれば満足度に繋がるか（各要因が満足度に影響を 及ぼすカットオフ值）を探索すること，（3）満足度に基づく 被験者の類型化を行うこと.

アンケート調査分析において, 一般的に用いられる統計 手法が重回帰分析である。ただし，重回帰分析では，上記の 目標（1）は達成できるものの，目標（2）（3）を達成することは できない，そのため，本論文では，目標 (1)〜（3）を達成する ための統計的方法として適応的指示モデル (AIM ; Adaptive Index Model，以下AIM法）［1］を応用する。

2節では，成都市の概要について触れる，3節では，街路景 観評価に関する既存研究について述べるとともに, 本研究の 位置づけ拈よび目標について詳述する，4節では，アンケート 調查の概要と要約統計量について述べる，5節では，AIM法 を用いて街路景観の評価を行う。ここでは, 順序付きクラス ターの考察を行うとともに, 調査地点毎での傾向について 考察を行う。 6節では, 得られた結果を整理し, 結びに代える. 


\section{2. 成都市の概要}

成都市は, 中華人民共和国 (以下, 中国) 四川省の省都であ る。四川省は, 中国西南部, 長江の上流域に位置する省である. 周囲は秦嶺山脈，チベット高原，および雲貴高原に囲まれ， 中部㧍よび東部には四川平原が広がっている，とくに，四川 平原は，肥沃な土壤が分布していることから，「天府の国」と 呼ばれている。

省都である成都市は，副省級市［注3］であり，四川省の ほぼ中央に位置する。三国時代には，蜀の都として発展したこ とでも有名であり，その他にも多くの歴史的遺産が点在する。 人口は, 2017 年に扮いて, 1607.47 万人 (中国第4位)であり， 東京都 (1395.16万人) を上回る.

成都市は，急激な人口増加に応えるために，地下鉄などの 公共交通インフラの整備が急激に進められており，2021年に は，新空港 (成都天府国際空港) が開港予定である。一方で,
成都市は，中国政府が「国家新型都市化計画」を発表する前 に, 同様の考え方のもと, 都市農村総合計画に取り組むなど, 先進的な政策を行っている [2].

\section{3. 既存研究と本研究の位置づけ}

街路評価に関する研究には，都市計画を中心に数多くの 報告がある. 表 1 は, 代表的な先行研究の概要を表している. 街路評価に関する研究には, 街路の写真あるいはCG 画像を 用いた評価実験に基づく方法（No.1～6）とアンケート調査 に基づく方法（No.7～9）がある。

街路の写真を用いた評価実験に基づく方法には，(1) 写真 の景観が類似するものをグループ分けする実験（No.1, 2), あるいは，(2) SD法に基づく評価実験（No.4, 5) がある。 （1）の場合には, 同じグループに属する頻度に基づく類似度行 例を用いた多変量解析を用いることで，街路の類型化あるい

表1 街路景観に対する既存研究の要約

\begin{tabular}{|c|c|c|c|c|c|}
\hline No & 論文 & 研究の目的 & 実験·調査の方法 & 統計手法 & 結論 \\
\hline 1 & $\begin{array}{l}\text { 細川ら [3], } \\
\text { 窪田 [4] }\end{array}$ & 街路景観の類型化 & $\begin{array}{l}\text { 街路の写真を被験者に分類し } \\
\text { てもらい, 同じグループに分類 } \\
\text { された頻度を計測している. }\end{array}$ & $\begin{array}{l}\text { 同じグループに属する頻度を } \\
\text { 類似度とした非量多次元尺 } \\
\text { 度法による類型化 }\end{array}$ & $\begin{array}{l}\text { 分類の規定要因として空間量, 側道土 } \\
\text { 地利用, 緑量が影響していることが示 } \\
\text { 唆されている. }\end{array}$ \\
\hline 2 & 楊ら $[5,6]$ & $\begin{array}{l}\text { 街路景観の印象に } \\
\text { 対する影響要因の } \\
\text { 探索 }\end{array}$ & $\begin{array}{l}\text { 街路の写真を被験者に分類 } \\
\text { してもらい, 同じグループに } \\
\text { 分類された頻度を計測して } \\
\text { いる, }\end{array}$ & \begin{tabular}{|l|} 
同じグループに属する頻度に \\
基づく非類似度行列に対する \\
多変量 CART 法 [7] あるいは \\
MARS 法 [8]による影響要因 \\
の探索
\end{tabular} & $\begin{array}{l}\text { 歩道幅, 周辺の商店の有無, および } \\
\text { 道路舗装が街路景観の類型化に影響 } \\
\text { を及ぼすことが指摘されている。 }\end{array}$ \\
\hline 3 & 山田ら [9] & \begin{tabular}{|l|} 
街路上の高架構造 \\
物の景観的影響の \\
評価
\end{tabular} & $\begin{array}{l}\text { 高架構造物のCGによるモン } \\
\text { タージュ写真を用いた認知 } \\
\text { 評価実験を行っている. }\end{array}$ & \begin{tabular}{|l|} 
数量化III類による調査地点の \\
類型化, 数量化I類による高架 \\
構造物の形状の影響の評価 \\
\end{tabular} & \begin{tabular}{|l|} 
街路景観タイプと高架構造物のデザイ \\
ンの関連性に関する考察されている.
\end{tabular} \\
\hline 4 & 天野ら [10] & \begin{tabular}{|l|} 
街路景観に対する \\
認知構造の評価
\end{tabular} & $\begin{array}{l}\text { 街路の写真をSD法によって } \\
\text { 印象を評価してもらう認知 } \\
\text { 評価実験を行っている. } \\
\end{array}$ & 䌸造分析による認知構 & \begin{tabular}{|l|} 
「歩きやすさ」と「霉囲気」が「たのし \\
さ」に影響を与え, そして「また来てみ \\
たい」と考えることを指摘している. \\
\end{tabular} \\
\hline 5 & 北村 [11] & \begin{tabular}{|l|} 
街路景観の印象に \\
対する認知構造の \\
探索と空間的要因 \\
の評価
\end{tabular} & $\begin{array}{l}\text { 街路の写真をSD法によって } \\
\text { 印象を評価してもらう認知 } \\
\text { 評価実験を行っている. }\end{array}$ & \begin{tabular}{|l|} 
因子分析による認知構造の探 \\
索㧍よび, 因子得点に対する \\
数量化I類による空間的要因 \\
の評価 \\
\end{tabular} & $\begin{array}{l}\text { 街路景観に対する認知構造には「調和 } \\
\text { 性」「賑やか」「親密性」があり,街路 } \\
\text { 景観の色彩およびテクスチャが晾響 } \\
\text { を及ぼすことを述べている. }\end{array}$ \\
\hline 6 & 篠原ら [12] & \begin{tabular}{|l|} 
側道の建物が街路 \\
景観に及ぼす影響 \\
を計量的に評価
\end{tabular} & $\begin{array}{l}\text { CGを用いて画像を作成し, } \\
\text { その街路に佇んでいる視点に } \\
\text { おいて, 圧迫感, 総合感, 囲ま } \\
\text { れ感を SD法により評価する } \\
\text { 認知評価実験を行っている. }\end{array}$ & \begin{tabular}{|l|} 
各指標に対して, CGによる建 \\
物の空間的指標を説明変数, \\
SD法による評価結果を応答変 \\
数にした回帰分析による評価
\end{tabular} & $\begin{array}{l}\text { 街路周辺の建物の構造とそれに対す } \\
\text { る印象に対する数理モデルを構築し } \\
\text { ている. }\end{array}$ \\
\hline 7 & Li et al. [13] & \begin{tabular}{|l} 
成都市と東京 23 区 \\
の街路景観に対 \\
する認知特性に対 \\
する空間的要因の \\
比較
\end{tabular} & $\begin{array}{l}\text { 成都市と東京 } 23 \text { 区に居住す } \\
\text { る学生に対して, 幹線道路を } \\
\text { 想像してもらい, その街路に } \\
\text { 対する印象をアンケートに } \\
\text { より調査している. }\end{array}$ & \begin{tabular}{|l|} 
因子分析によって得られた評 \\
価指標を応答, 空間的要因に \\
対する調査項目を説明変数に \\
用いたランダムフォーレスト \\
法 [14]による評価
\end{tabular} & $\begin{array}{l}\text { 街路景観の「美しさ」については, 道路 } \\
\text { 舗装が最も影響しており,「賑やかさ」に } \\
\text { つては, 人售来の多さが最も影響が } \\
\text { あり,「親近性」については, 周辺の店舗 } \\
\text { の影響が高いことを指摘している. }\end{array}$ \\
\hline 8 & 李ら [15] & \begin{tabular}{|l} 
成都市と東京 23 区 \\
の街路景観に対 \\
する認知特性に対 \\
する空間的要因の \\
比較
\end{tabular} & $\begin{array}{l}\text { 成都市と東京 } 23 \text { 区に居住す } \\
\text { る学生に対して, 身近な街路 } \\
\text { を想像してもらい, その街路 } \\
\text { に対する印象をアンケート } \\
\text { により調査している. }\end{array}$ & \begin{tabular}{|l|} 
「快適性」,「美しさ」,「親近性」, \\
「歩きやすさ」の満足度を応答, \\
空間的要因に対する調査項目 \\
を説明変数に用いた条件付き \\
推測樹木法 [16]による評価
\end{tabular} & $\begin{array}{l}\text { 道路舗装, 周辺の建物の煩雑さが } \\
\text { 「快適性」「美しさ」に影響を与え, } \\
\text { 「親近性」については東京と成都で印 } \\
\text { 象が異なることを述べている. また, } \\
\text { 「歩きやすさ」には障害物の多さが影 } \\
\text { 響することを指摘している. }\end{array}$ \\
\hline 9 & 中山ら [17] & $\begin{array}{l}\text { シェアド・スペー } \\
\text { スに対する意識調 } \\
\text { 査の実施 }\end{array}$ & $\begin{array}{l}\text { ドライバーを対象としたWeb } \\
\text { アンケート調査および, 街頭 } \\
\text { における歩行者を対象とした } \\
\text { ヒアリング調査している. }\end{array}$ & \begin{tabular}{|l|} 
シェアド・スペースの有無で街 \\
路を2群に分けたときの, 調査 \\
項目毎での比較にt検定を利用
\end{tabular} & $\begin{array}{l}\text { シェアド・スペースは, ドライバーが } \\
\text { 歩行者に気を配る傾向を醸成し, その } \\
\text { 結果として, 歩行者が街路の需囲気を } \\
\text { ポジティブに捉える傾向があること } \\
\text { を述べている. }\end{array}$ \\
\hline
\end{tabular}


は写真内の空間的要因 (例：ゴミの量や道路舗装) との関連性 が評価される。また，(2)の場合には, 調査項目の評価得点に 対する空間的要因の影響 (すなわち, 因果効果) が評価される. $\mathrm{CG}$ 画像を用いた研究では, 特定の要因 (例えば, 高架構造物) に焦点が当てられており,その要因の程度を変化させたとき の調査項目 (応答変数)の傾向変化が考察される (No.3, 6).

評価実験に基づく方法では, 被験者が予め設定した街路景 観を評価する。これに対して, アンケート調査に基づく方法で は, 対象の街路を被験者が選定する場合 (No.7, 8), あるいは, 街頭において周辺の街路を被験者が評価する場合 (No.9)があ る、したがって, 被験者が評価する街路景観が調査者(研究者) によって予め規定されない.アンケート調査に基づく方法で は, 街路景観の認知的側面に着目したもとで, 周辺の物理的 要因との関連性を評価する場合 (No.7, 8), あるいは, 個々の 調査項目の評価を行う場合（No.9）がある.

街路の写真を用いた評価実験に基づく方法の多くが, 数十 枚の実験に用いられる写真あるいはCG画像などを用いて行 われる。ただし，実際の街路景観は多岐にわたり，それらの 影響を吟味するには十分な数であるとはいえない，また， CG 画像（No.6）あるいはモンタージュ画像（No.3）はリアリティ に欠ける.

アンケート調査に基づく方法において, 対象となる街路を 被験者に想像してもらう研究は, 想像した街路の位置だけで なく, 思い浮かべた街路の情景が不明であるため, 多分に曖 昧さを秘めている.

そのため, 本研究では, 街頭に扔けるアンケート調査に 基づく方法により, 街路の利便性に対する調査を行った。 なお, 街路評価における研究では, 街路景観の認知的な評価 あるいは街路の特定の空間的要因（例えば，高架構造物ある いはシェアド・スペース）に対する評価に終始しており， 街路の利用者の利便性の観点から調查を行っている報告は殆 どない.このことが, 街頭でのアンケート調査を行った動機 の一つである。

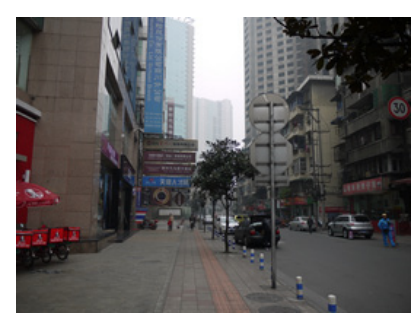

（a）通勤地区

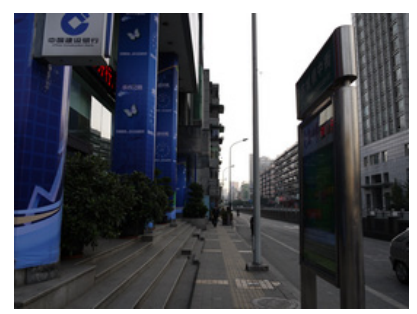

(e) 駅付近

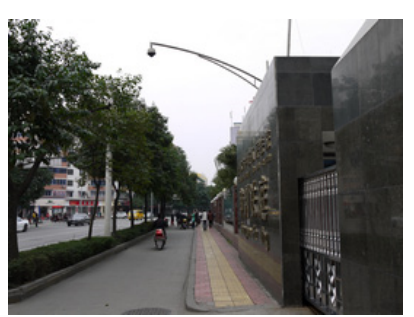

（b）通学地区

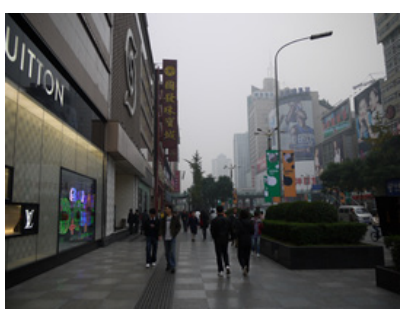

(f) 商業地区

\section{4. アンケート調査の概要}

\section{1 調查方法}

成都市でのアンケート調査は, 成都市政府の協力のもと, 市街地に扔いて，徒歩および自転車で通行する一般市民に 対して実施した。この調査は，当該アンケートを行った地点 の街路景観を見渡してもらい, 調査票に回答してもらった. このとき，調査地点の例を図 1 に示す.

アンケート項目については, 北村 $[11]$, 楊ら $[5,6]$ および Li et al. [13] を参考に設定した。 アンケートは，1が「不満で ある (当てはまらない)」，2は「やや不満である(やや当ては まらない)」，3は「どちらでもない」４は「やや満足している (やや当てはまる)」，5は「満足している(当てはまる)」の 5 件法が用いられた。つまり，数字が 1 に近づくほど不満で あり，5に近づくほど満足していることを表している。 なお， アンケート項目の詳細は, 補遺 1 を参照されたい.

\section{2 被験者の概要}

アンケート調査は, 2016年 12 月から 2017 年1月にかけて 実施された，被験者数は，歩行者が2,291名，および自転車 利用者が751名である。

表 2 は, 被験者の背景を表している。性別は, いずれの場 合でも若干男性のほうが多かった。年齢の平均值はおおよそ 35歳であった，学歴は，高校生以下が最も高く，いずれの場 合にも半数以上だった，職歴の分布には，若干の違いが認め られた，徒歩の被験者では, 会社員が最も多く, 次いでフリー ター, 学生の割合が高かった。自転車利用者では, 会社員が 最も高く, 次いで, 商業.サービス業, 学生の割合がかかった. 月収では, $4000 〜 6000$ 人民元の割合が高かった。 また, 1200 人民元以下の割合が $20 \%$ 以上存在するが，これは，学生 の割合の高さが反映していると考えられる，成都市住民で あるか否かについては，扔拉よそ $80 \%$ が成都住民であった。 利用時間は, 自転車の利用者のほうが徒歩に比べて長かった。

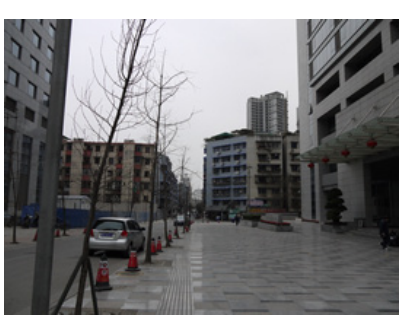

（c）住居地区

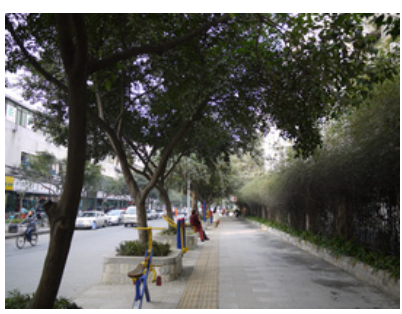

（g）公園付近

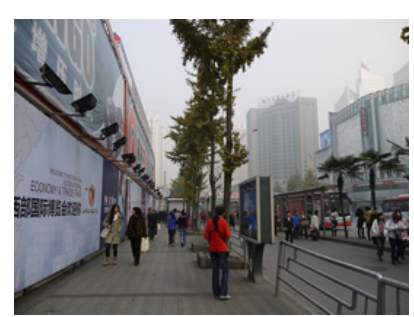

(d) バス停付近

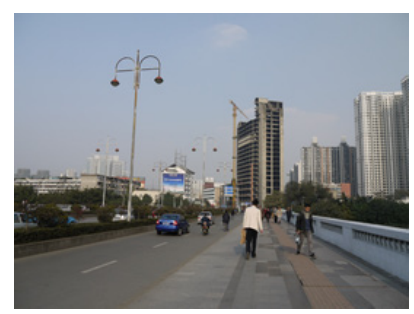

(h) その他

図1 調查地点の写真 
表2 被験者の概要

\begin{tabular}{|c|c|c|c|c|c|c|c|}
\hline \multirow{3}{*}{ 性別 } & \multirow[b]{3}{*}{$\begin{array}{l}\text { 男 } \\
\text { 女 }\end{array}$} & \multicolumn{3}{|c|}{ 歩行 $(\mathrm{N}=2,291)$} & \multicolumn{3}{|c|}{ 自転車（N=751） } \\
\hline & & \multicolumn{2}{|c|}{ 要約 } & \multirow{2}{*}{$\begin{array}{c}\text { 欠測 } \\
5\end{array}$} & \multicolumn{2}{|c|}{ 要約 } & \multirow{2}{*}{$\frac{\text { 欠測 }}{0}$} \\
\hline & & $\begin{array}{l}1,215 \\
1,071\end{array}$ & $\begin{array}{l}(53.0 \%) \\
(46.7 \%)\end{array}$ & & $\begin{array}{l}415 \\
336\end{array}$ & $\begin{array}{l}(55.3 \%) \\
(44.7 \%)\end{array}$ & \\
\hline 年齢：平均 $(\mathrm{SD})$ & & 36.1 & $(16.0)$ & 0 & 34.2 & (13.9) & 0 \\
\hline 学歴 & $\begin{array}{l}\text { 高校以下 } \\
\text { 短大·大学 } \\
\text { 大学院 }\end{array}$ & $\begin{array}{r}1,158 \\
1,044 \\
78\end{array}$ & $\begin{array}{r}(50.5 \%) \\
(45.6 \%) \\
(3.4 \%)\end{array}$ & 11 & $\begin{array}{r}392 \\
335 \\
21\end{array}$ & $\begin{array}{r}(52.2 \%) \\
(44.6 \%) \\
(2.8 \%)\end{array}$ & 3 \\
\hline 職業 & $\begin{array}{l}\text { 公務員 } \\
\text { 会社員 } \\
\text { 個人経営者 } \\
\text { 第 } 1 \text { 次産業 } \\
\text { 商業サービス } \\
\text { 生産・運送従事者 } \\
\text { フリーター } \\
\text { 学生 }\end{array}$ & $\begin{array}{r}200 \\
503 \\
259 \\
81 \\
303 \\
89 \\
432 \\
423\end{array}$ & $\begin{array}{r}(8.7 \%) \\
(22.0 \%) \\
(11.3 \%) \\
(3.5 \%) \\
(13.2 \%) \\
(3.9 \%) \\
(18.9 \%) \\
(18.5 \%)\end{array}$ & 1 & $\begin{array}{r}69 \\
165 \\
86 \\
44 \\
106 \\
49 \\
100 \\
131\end{array}$ & $\begin{array}{r}(9.2 \%) \\
(22.0 \%) \\
(11.5 \%) \\
(5.9 \%) \\
(14.1 \%) \\
(6.5 \%) \\
(13.3 \%) \\
(17.4 \%)\end{array}$ & 1 \\
\hline 月収 (人民元) & $\begin{array}{l}1200 \text { 以下 } \\
1200 \sim 2000 \\
2000 \sim 4000 \\
4000 \sim 6000 \\
6000 \sim 8000 \\
8000 \sim 10000 \\
10000 \text { 以上 }\end{array}$ & $\begin{array}{r}555 \\
234 \\
619 \\
580 \\
209 \\
80 \\
11\end{array}$ & $\begin{array}{l}(24.2 \%) \\
(10.2 \%) \\
(27.0 \%) \\
(25.3 \%) \\
(9.1 \%) \\
(3.5 \%) \\
(0.5 \%)\end{array}$ & 3 & $\begin{array}{r}162 \\
82 \\
227 \\
188 \\
58 \\
29 \\
5\end{array}$ & $\begin{array}{l}(21.6 \%) \\
(10.9 \%) \\
(30.2 \%) \\
(25.0 \%) \\
(7.7 \%) \\
(3.9 \%) \\
(0.7 \%)\end{array}$ & 0 \\
\hline 成都住民 & $\begin{array}{l}\text { はい } \\
\text { いいえ }\end{array}$ & $\begin{array}{r}1,791 \\
484\end{array}$ & $\begin{array}{l}(78.2 \%) \\
(21.1 \%)\end{array}$ & 16 & $\begin{array}{l}629 \\
115\end{array}$ & $\begin{array}{l}(83.8 \%) \\
(15.3 \%)\end{array}$ & 7 \\
\hline 利用時間 & $\begin{array}{l}5 \text { 分以内 } \\
5 \sim 10 \text { 分 } \\
10 \sim 20 \text { 分 } \\
20 \sim 30 \text { 分 } \\
30 \text { 分以上 }\end{array}$ & $\begin{array}{r}95 \\
492 \\
803 \\
431 \\
468\end{array}$ & $\begin{array}{r}(4.1 \%) \\
(21.5 \%) \\
(35.1 \%) \\
(18.8 \%) \\
(20.4 \%)\end{array}$ & 2 & $\begin{array}{r}13 \\
112 \\
310 \\
180 \\
136\end{array}$ & $\begin{array}{r}(1.7 \%) \\
(14.9 \%) \\
(41.3 \%) \\
(24.0 \%) \\
(18.1 \%)\end{array}$ & 0 \\
\hline 目的 & $\begin{array}{l}\text { 通勤・通学 } \\
\text { レジャー・ショッピング } \\
\text { トレーニング・娛楽 }\end{array}$ & $\begin{array}{r}1,044 \\
807 \\
433\end{array}$ & $\begin{array}{l}(45.6 \%) \\
(35.2 \%) \\
(18.9 \%)\end{array}$ & 7 & $\begin{array}{l}388 \\
223 \\
137\end{array}$ & $\begin{array}{l}(51.7 \%) \\
(29.7 \%) \\
(18.2 \%)\end{array}$ & 3 \\
\hline
\end{tabular}

これは，交通アクセスの利便性の高い自転車の利用者のほう が長距離を移動するためであると推察される。利用目的は, 通勤・通学の割合が最も高く, 次いで, レジャー・ショッピ ングであった。

\section{5. 適応的指示モデルに基づく利便性評価への影響}

本解析の目標は, (1) 満足度に影響を及ぼす要因（影響要因） を評価すること，（2）影響要因をどの程度評価すれば満足度 に繋がるか (各要因が満足度に影響を及ぼすカットオフ值)を 探索すること，（3）満足度に基づく被験者の類型化を行うこ と、にある、

目標 (1) は, 総合的満足度 (調査項目 Q22) を応答とした, 回帰的アプローチが必要であることを意味する。目標 (2) は, アンケート調査分析に頻用される重回帰分析よりも, 回帰木 のようなプロダクション・ルールに基づく方法のほうが適し ていることを意味する。ただし, 回帰木で得られるクラスター (リーフ) は, 互いに異なる応答 (利便性) の予測值を持つこ
とは保証されない,すなわち, 回帰木では, 目標 (3)を達成 できない，そのため, 本論文では, 目標 $(1) \sim(3)$ を達成す る方法として適応的指示モデル (AIM) 法 [1] を用いる.

AIM 法は, 説明変数に基づく指示関数（プロダクション． ルール）の総和を用いた単回帰モデルによって構成される 回帰分析法である. この方法は, 説明変数による複数のプロ ダクション・ルールを満たしている総和によって得点化が 行われる（これにより, 目標 (1)（2）が達成できる). また, 点数に基づくクラスターが構成される（これにより, 目標 (3) が達成できる). な㧍, 本論文では, 点数に基づくクラスター を順位付きクラスターと呼ぶ.

本節では, AIM法による解析結果を提示するとともに, 結果を考察する. AIM 法の概要については, 補遺 2 を参照さ れたい.このとき, 応答は総合的満足度 $(\mathrm{Q} 22)$, 説明変数は, その他の質問項目 $(\mathrm{Q} 1 \sim \mathrm{Q} 21)$ とした。 また, AIM法の指示 関数 (ルール) を選定するときに用いられるスコア検定統計量 の有意水準 $\alpha$ は 0.05 とし, ルール数の上限は, 質問項目の 個数 (21 個) とした. 


\section{1 歩行者に対する調査結果}

歩行者を対象とした歩道に対するアンケート調査に対して， AIM法を適用したときのルールを以下に示す。
R.1：Q1（安全である）
$\geqq 4 \quad[73.2 \%]$
R.2：Q2（連続的である）
$=5 \quad[19.2 \%]$
R.3：Q11（道幅が広い)
$=5[20.4 \%]$
R.4：Q16 (夜間照明が良い) $\geqq 3 \quad[83.3 \%]$

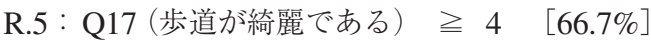

上記のルールにおいて，［］内の割合は，ルールに該当する 被験者の割合（サポート）を表している，推定されたルール が5個であることから, 0点から5点までの総得点が得られる。

Q2 (直線的である) およびQ11（道幅が広い）は，5 (非常に 良い) と回答しなければ得点が得られなかった。つまり, 歩道 幅あるいは歩道の連続性といった，歩道のインフラに対する 項目は，他のルールに比べてシビアに評価されていることが 示唆された。一方で, 夜間照明については, 3 (どちらでもない) 以上の評価があれば得点が得られることから, 不満 (2以下) でなければ良いことが分かった。成都市は大都市であり， 店舗などの照明が深夜まで灯っている。 このことが, 歩道周 囲の明るさがアンケート調査に反映されたと推察される.

各ルールのサポートでは，R.2およびR.3が極端に低かっ た。これらのルールは，5(非常に良い)でなければならない ことが反映されたと思われる。

図 2 は, AIM法によって推定された得点 (順序付きクラスター) と総合的満足度（Q22）の関係を表している。ここで, 破線は, データ集合全体での総合的満足度 (Q22)の平均值 (3.72) を 表している. その結果, 5 点の場合に総合的満足度の平均值 - 標準偏差（図2のエラーバーの下限值）が全体平均を大き く上回った．また，4点のエラーバーの下限值は僅かに全体 平均を下回ったものの，打抢よそ満足していると考えられる. 得点が 4 点以上になるには, 歩道の連続性 (直線性) あるいは 道幅といった, 歩道のインフラに関する項目を利用者が満足 しなければならないことがわかった。一方で, 得点が1点以 下の被験者は, その歩道に対する総合的満足度が全体平均に 比べて極めて低かった。

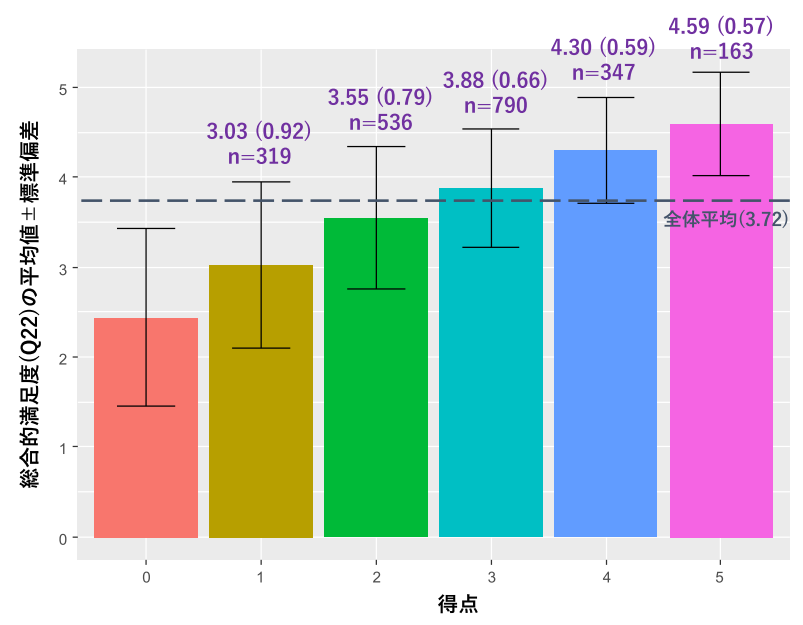

図2 歩行者の得点に対する総合的満足度の平均値

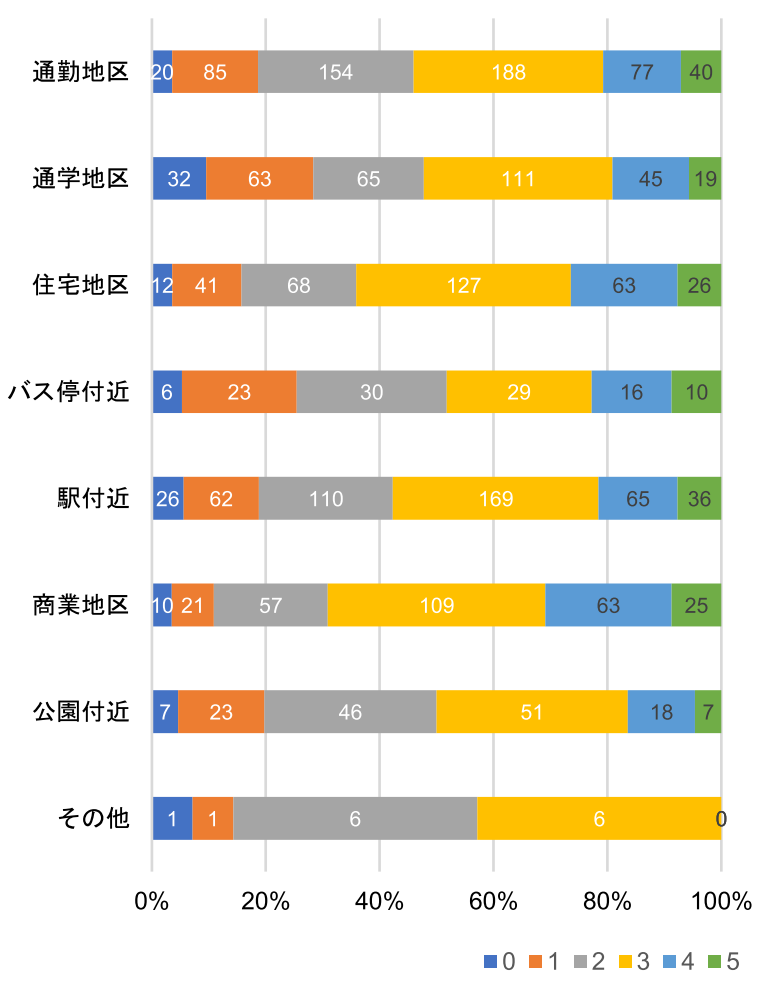

図3 歩行者に対する得点と調査地区の関係

図3は, 調査地区を 8 カテゴリ（通勤地区, 通学地区, 住宅 地区, バス停付近, 駅付近, 商業地区, 公園付近, その他）に 分けたときのそれぞれの地区における得点(順序付きクラス ター）の分布を表している．商業地区および住宅地区に掞い て4点以上の被験者（総合的満足度が高いクラスターに属する 被験者)が多かった。一方で, 通学地区およびバス停付近では, 1 点以下の被験者（総合的満足度が全体平均を下回るクラス ターに属する被験者) が多かった。

図4は,ルール毎の傾向を表している。ここで, 縦軸の適合 割合とは，各地区でのルールを満たしている割合／全体での

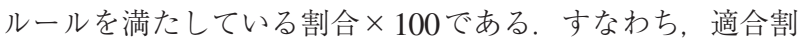
合が 100 以上の場合には，全体に比べて当該ルールを満たし ている被験者が多いことを意味する。一方で，100を下回る 場合には，全体に比べて低いことを意味する，それぞれの 地区での傾向を以下に示す (その他を除く) :

(1) 通勤地区

道幅 (Q11/R.5 : この歩道の幅は広い)の適合割合は87.7であ り，著しく低かった，その他のルールは，全体(適合割合=100) とおおよそ同程度であった。

(2) 通学地区

すべてのルールが全体平均を下回った。 とくに，安全性 および道幅の適合割合が，それぞれ 78.9 および 88.9 であり， 非常に低かった.

(3) 住宅地区

連続性（Q2/R.2：この歩道は連続的（直線的）である)の

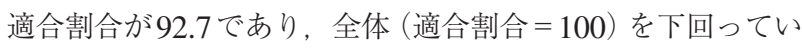
るものの, その他のルールは上回った. とくに, 道幅の適合 割合が122.1であり，著しく高かった。 


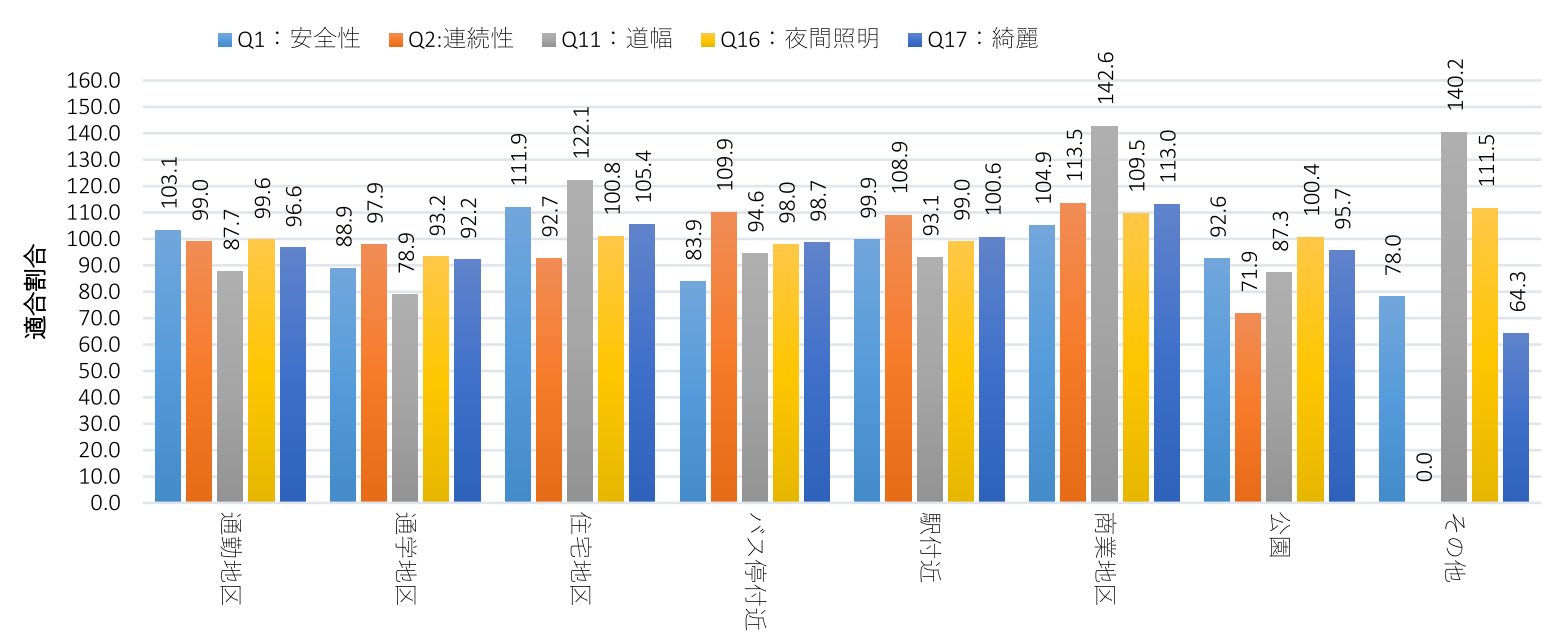

図4 歩行者における全体でのルール充足割合を 100 としたときの地区別のルール充足割合の相対評価

(4) バス停付近

連続性以外の項目が全体（適合割合＝100）を下回った， とくに, 安全性の適合割合が 83.9 であり, 著しく低かった.

(5) 駅付近

道幅の適合割合が93.1であり，若干低いものの，その他の

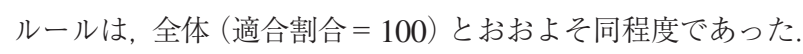

(6) 商業地区

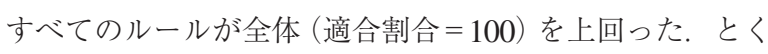

に，道幅の適合割合が140.2であり，非常に高かった。

(7) 公園付近

夜間照明 (Q16/R.4：この歩道の夜間照明は良好である) の 適合割合は全体平均を僅かに上回るものの, その他のルールは 全体を下回った，とくに，連続性，道幅の適合割合は非常に 低かった。

\section{2 自転車に対する調査結果}

自転車を対象とした歩道に対するアンケート調查に対して, AIM法を適用したときのルールを以下に示す。
R.1：Q1（安全である）
$\geqq 4 \quad[68.1 \%]$
R.2：Q6 (歩道との分離)
$\geqq 4 \quad[21.4 \%]$
R.3：Q16 (自転車道路が綺麗)
$=5 \quad[85.5 \%]$
R.4：Q20 (駐輪場の数)
$\geqq 3 \quad[25.6 \%]$

上記のルールに扔いて, [ ] 内の割合は, 当ルールに該当 する被験者の割合（サポート）を表している，推定されたルー ルが4個であることから, 0 点から 4 点までの総得点が得られる.

Q6 (歩道との分離) 抢よびQ16 (自転車道路が綺麗) に該当 するルール（R.2,R.3）のサポートが極端に低かった。つまり， 自転車道路扩よび駐輪場といった自転車用のインフラ整備は, 総合的満足度を引き上げる上で重要であるにもかかわらず, 十分にでないことが伺える.

図 5 は, AIM法によって推定された得点と総合的満足度 （Q22）の関係を表している。そその結果, 得点が4点（すべての ルールを満たす) の場合に, 総合的満足度の平均值 - 標準偏 差(図5のエラーバーの下限值)が全体平均 (3.71) を上回った. また, 得点が 3 点の場合のエラーバーの下限值は, 全体平均

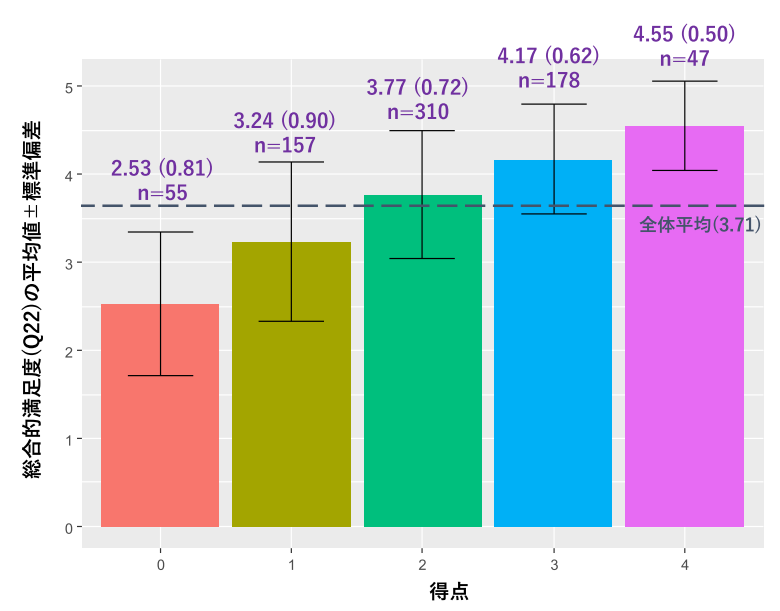

図5 自転車利用者の得点に対する総合的満足度の平均値

に比べて僅かに小さかったが，概㸚満足していると判断でき る. 一方で, 得点が1点以下の場合には, 全体平均を下回り, 0 点（すべてのルールを満たさない）の平均総合満足度は, 2.53 であり，極端に低かった。

図6は，調査地点を8カテゴリに分けたときのそれぞれの地区 に抒ける得点(順序付きクラスター)の分布を表している。 バス停 近くおよび商業地区では, 3 点以上の被験者（総合的満足度が 高いクラスターに属する被験者) が多かった。一方で, 通学地区 および公園付近では, 1 点以下の被験者 (総合的満足度が低い 被験者)が多かった。公園付近は, 3 点以上の被験者割合につ いても高いことから, 满足/不満足の評価が明確に分かれた.

図7は, 得点を構成するルール毎の傾向を表している。 それ ぞれの地区での傾向を以下に示す（その他を除く）：

（1）通勤地区

駐輪場の数 (Q20/R.4 : この自転車道路の駐輪場の数に满足 している)の適合割合が全体(適合割合 $=100$ )を大きく上回っ た、その他のルールは，全体とほぼ同じであった（適合割合 が扮扰よそ100であった)。

(2) 通学地区

歩道との分離 $(\mathrm{Q} 6 / \mathrm{R} .2$ : この歩道と自転車道路のストリート スペースに満足している）の適合割合が全体（適合割合 $=100 ）$ 


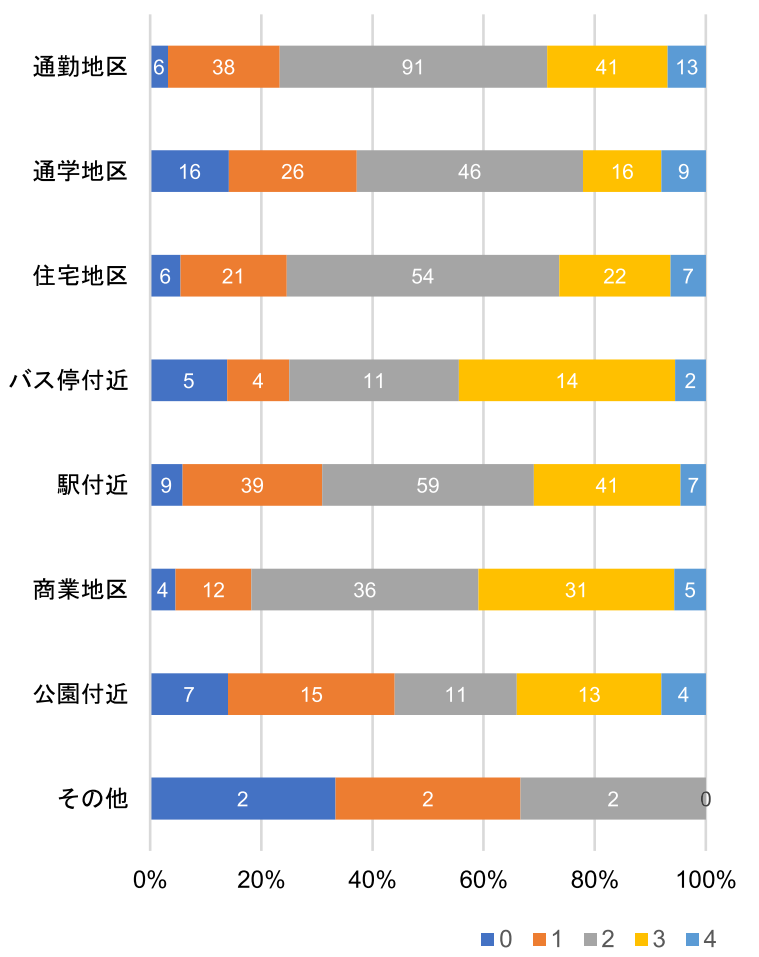

図6 自転車利用者に対する得点と調査地区の関係

を大きく上回ったものの, その他のルールの適合割合は全体 を下回った(適合割合が100未満であった)。とくに，駐輪場 の数の適合割合が 69.1 であり, 非常に低かった。

(3) 住宅地区

歩道との分離および駐輪場の数の適合割合がそれぞれ 89.3 および69.1であり, 著しく低かった. すなわち, 自転車道路 に対するインフラ整備に対する満足度が低かった。

(4) バス停付近

歩道との分離および駐輪場の数の適合割合は, それぞれ 129.9 および130.1であり, 非常に高かった（自転車道路のイン フラ整備に満足する被験者が多かった). 一方で, 安全性 (Q1/R.1：この自転車道路は安全である) の適合割合が 93.8 であり，若干低かった。

\section{（5）駅付近}

歩道との分離に対する適合割合が87.4であり, 著しく低かっ た。一方で，その他のルールは，全体とほぼ同じであった (適合割合がおおよそ100であった)。

(6) 商業地区

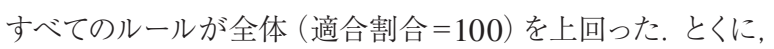
歩道との分離の適合割合が137.9であり，非常に高かった。

（7）公園付近

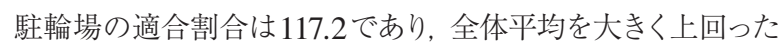

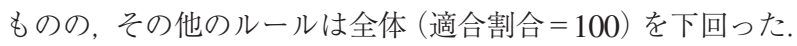
とくに, 安全性および歩道との分離の適合割合は, それぞれ 82.2 および74.8であり，非常に低かった

\section{3 まとめ}

図 8 は, 各調査地区の平均得点を標準化（以下, 標準化得点) したときの，歩行者と自転車利用者の散布図である。通学 地区と公園付近は，歩行者および自転車利用者のいずれにお いても標準化得点が負值であり, 全体の平均得点未満であっ た.一方で, 商業地区は, 標準化得点が正值であることから, 全体の平均得点を上回った，バス停付近は，歩行者では負值

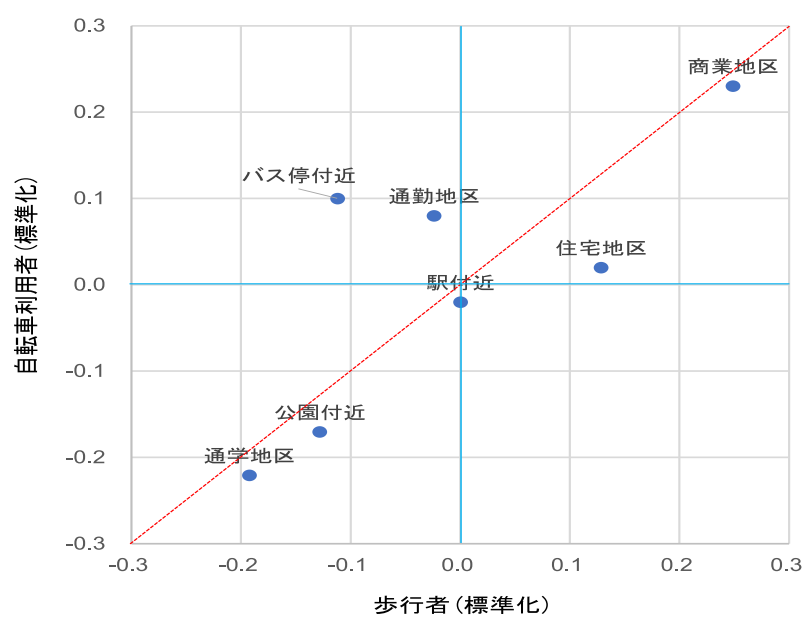

図8 歩行者と自転車利用者の得点の関連性の散布図

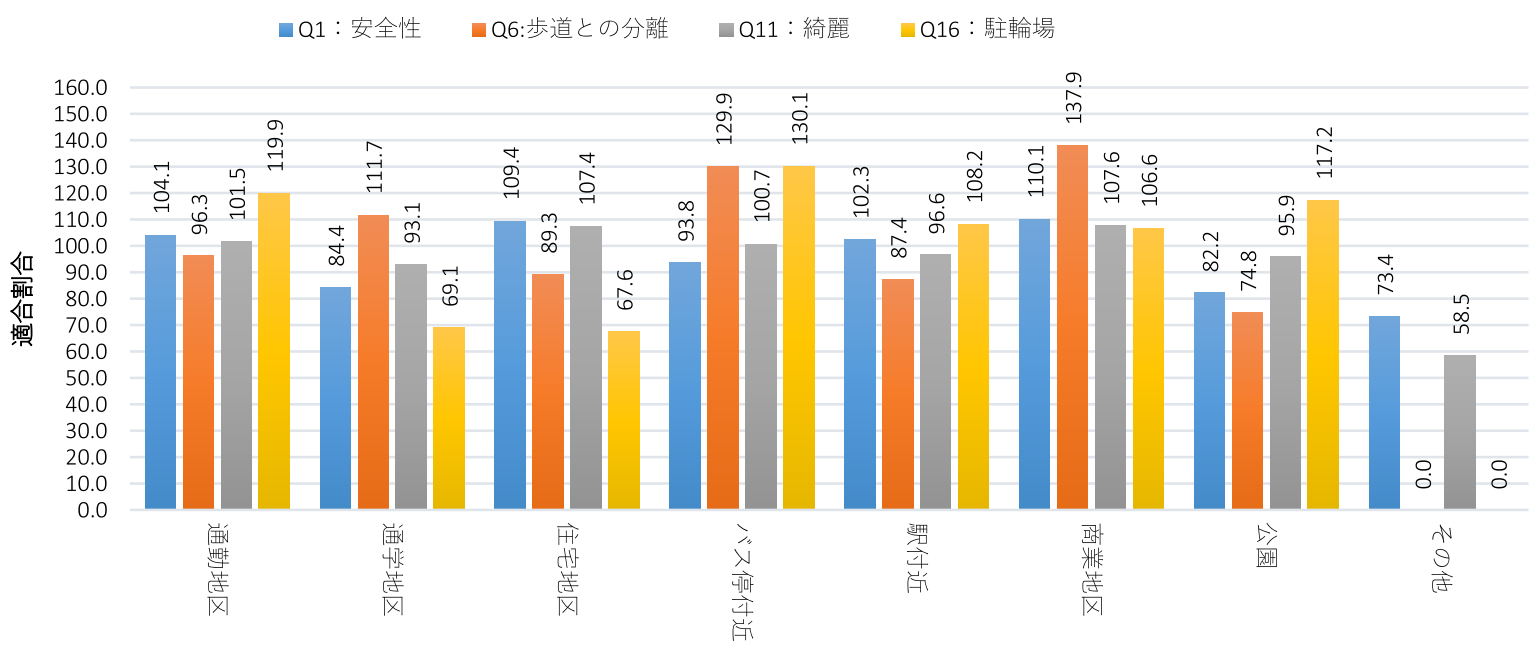

図7 自転車利用者における全体でのルール充足割合を 100 としたときの地区別のルール充足割合の相対評価 
であるものの, 自転車利用者では正值であった。 したがって, バス停付近の街路は, 歩行者には不評だが, 自転車利用者で は好評だった。

表3は,ルールと各調査地区での組み合わせの結果を要約 している。ここで，×は適合割合が $80 \%$ 未満のルール，、は 90\%未満のルール，○は $110 \%$ 以上のルール，○は120\%以上 のルールである.

先ず，選択されたルールを省察する，歩行者および自転車 のいずれにおいても, 安全性（いずれもQ1）および街路の 綺麗さ(歩行者 $\mathrm{Q} 17$, 自転車 Q16)がルールに含まれた。 また, 歩行者では, 道幅 (Q11) および夜間照明 (Q16), 自転車で は歩道との分離（ストリーススペース）(Q6）および駐輪場 (Q20)がルールに選ばれた，これらのルールは，道路のイン フラに関連していることから，アクセス方法によって道路イ ンフラに対する関心が異なることが示唆された.

次いで, 調査地区別での傾向を評価する。通勤地区では, 歩行者において道幅に対するルール $\left(\mathrm{R}_{\mathrm{W}} .3\right)$ を満たす割合が 低かった。一方で, 自停車利用者に対する駐輪場のルール （RB.4）を満たす割合が高かった，通学地区では，歩行者にお ける道幅に対するルール $\left(\mathrm{R}_{\mathrm{W}} .3\right)$, 自転車利用者に対する駐 輪場のルール（R $\mathrm{R}_{\mathrm{B}}$.4）を満たす被験者割合が非常に低かっ た。また，歩行者および自転車利用者のいずれに抏いても， 安全性に対するルール（R $\mathrm{W} .1 ）$ の被験者割合が低かった. このことが, 平均合計得点の低さに影響していることが推察 される. 同様に平均合計得点が低かった公園付近では, 歩行 者では連続性に対するルール $\left(\mathrm{R}_{\mathrm{W}} .2\right)$, 自転車利用者では 歩道との分離に対するルール $\left(\mathrm{R}_{\mathrm{B}}\right.$. 2$)$ を満たす割合が非常に 低かった。

一方で，歩行者拉よび自転車利用者のいずれにも平均合計 得点が高かった商業地区では, 歩行者では道幅に対する ルール $\left(\mathrm{R}_{\mathrm{W}} .3\right)$, 自転車利用者では歩道との分離に対する ルール（ $\left.\mathrm{R}_{\mathrm{B}} .2\right)$ を満たす割合が非常に高かった。

住宅地区では, 歩行者の道幅に対するルール ( $\left.\mathrm{R}_{\mathrm{W}} .3\right)$ を 満たす割合が高かった。図8では，住宅地区の歩行者に対す
る平均合計得点が全体に比べて高かったが, 道幅がこのこと に寄与していると考えられる。一方で, 自転車利用者の平均 合計得点が高かったバス停付近では, 歩行者との分離の ルール $\left(\mathrm{R}_{\mathrm{W}} .3\right)$ および駐輪場のルール $\left(\mathrm{R}_{\mathrm{B}} .4\right)$ を満たす割合 が高かったことから，バス停付近の自転車に対するインフラ 整備が満足度に繋がっていることが示唆された。

それぞれのルールを省察すると, 歩行者では道幅に対する ルール，自転車利用者では駐輪場および歩道との分離に対す るルールにおいて, 調査地点での賛否が分かれた。

\section{6. 結 び}

本論文では, 中国 成都市における街路の利便性に関する アンケート調査を実施した。調査データの統計解析では, 利便性に対する満足度を応答変数としたもとで, 適応的指示 モデル (AIM) 法を応用した。ここでは, 得られた結果を要約 し, 結びに代える.

・歩行者および自転車利用者（以下, 全利用者）のいずれ においても, 街路の安全性に関するルールが得られた。 すなわち, (街路整備との直接的な関連性はないものの) 街路周辺の防犯上の課題が認められた。同様に, 街路の 綺麗さ (ゴミがない) が, 歩行者および自転車利用者の いずれにおいても重要であることが示唆された。

・自転車では, 駐輪場の数, および歩道とのストリートス ケープのルールが得られた。 したがって, これらのイン フラ整備が自転車利用者の満足度に寄与していることが 示唆された。

- 通学地区では, 安全性および歩道と自転車道路のスト リートスケープが課題として挙げられた. 通学地区では, 通学時間帯において, 多くの児童・学生が通行する。 このことが，影響すると考えられる.

・公園地区では, 安全性, 道幅が課題として挙げられた。 成都市には，大通りから外れた場所に公園が点在するた め,このような結果が得られたと推察される。

表3 AIMによる解析のまとめ

\begin{tabular}{|c|c|c|c|c|c|c|c|c|}
\hline & & 通勤地区 & 通学地区 & 住宅地区 & バス停付近 & 駅付近 & 商業地区 & 公園付近 \\
\hline \multirow{5}{*}{$\begin{array}{l}\text { 歩 } \\
\text { 者 }\end{array}$} & $\mathrm{R}_{\mathrm{W}}$ 1 : 安全性 (Q1) $\geqq 4$ & & $\Delta$ & $\bigcirc$ & $\Delta$ & & & \\
\hline & $\mathrm{R}_{\mathrm{W}} \cdot 2:$ 連続性 $(\mathrm{Q} 2)=5$ & & & & & & $\bigcirc$ & $\times$ \\
\hline & $\mathrm{R}_{\mathrm{W} .3}$ : 道幅 $(\mathrm{Q} 11)=5$ & $\Delta$ & $x$ & () & & & (2) & $\Delta$ \\
\hline & $\mathrm{R}_{\mathrm{W}}$.4 : 夜間照明 $(\mathrm{Q} 16) \geqq 3$ & & & & & & & \\
\hline & $\mathrm{R}_{\mathrm{W}} .5$ : 綺麗さ $(\mathrm{Q} 17) \geqq 4$ & & & & & & $\bigcirc$ & \\
\hline \multicolumn{2}{|c|}{ 平均合計得点 (全体 : 2.63) } & $2.60(98.9)$ & $2.39(90.9)$ & $2.79(106.1)$ & $2.49(94.7)$ & $2.63(100.0)$ & $2.94(111.8)$ & $2.47(93.9)$ \\
\hline \multirow{4}{*}{$\begin{array}{l}\text { 䚁 } \\
\text { 俥 }\end{array}$} & $\mathrm{R}_{\mathrm{B}} \cdot 1$ : 安全性 $(\mathrm{Q} 1) \geqq 4$ & & $\Delta$ & & & & O & $\Delta$ \\
\hline & $\mathrm{R}_{\mathrm{B}} .2$ : 歩道との分離 $(\mathrm{Q} 6) \geqq 4$ & & O & $\Delta$ & () & $\Delta$ & () & $x$ \\
\hline & $\mathrm{R}_{\mathrm{B}} \cdot 3$ : 綺麗さ $(\mathrm{Q} 16)=5$ & & & & & & & \\
\hline & $\mathrm{R}_{\mathrm{B}}$.4：駐輪場 $(\mathrm{Q} 20) \geqq 3$ & 0 & $x$ & $x$ & () & & & 0 \\
\hline \multicolumn{2}{|c|}{ 平均合計得点 (全体：2.01) } & $2.09(104.0)$ & $1.79(89.1)$ & $2.03(101.0)$ & $2.11(105.0)$ & $1.99(99.0)$ & $2.24(111.4)$ & $1.84(91.5)$ \\
\hline
\end{tabular}

×は $80 \%$ 未満のルール，、は $\mathbf{\Delta} 90 \%$ 未満のルール，○は $110 \%$ 以上のルール，○は $120 \%$ 以上のルール， 平均得点の括弧は各地区の平均得点 / 全体の平均得点 $\times 100$. 
・バス停周辺では, 駐輪場のインフラに満足しているにも関 わらず，駅周辺ではそのような傾向が認められなかった．

・商業地区における街路景観については, 多くのルールを 満たしており，総合的満足度が高かった。

本研究では, 成都市のみを取り上げているが, 今後は中国 の他の都市での調査を通じて, 結果の安定性や精度を高める 必要がある。

\section{補遺1. 調査項目}

ここでは, 歩行者, 自転車, および電気自転車の利用者毎の 調査項目について記載する。 アンケートは，1 (不満である or 当てはまらない), 2 (やや不満である or やや当てはまらない), 3 (どちらでもない), 4 (やや満足している or やや当てはまる), 5 (満足している or 当てはまる) の5件法によって調査されて いる.

\section{A.1 歩行者に対する調查項目}

Q1この歩道は安全である

Q2この歩道は連続的（直線的）である

Q3この歩道の散歩は快適である

Q4この歩道を散歩することは楽しい

Q5この歩道と車道のストリートスペースに満足し ている

Q6この歩道と自転車道路のストリートスペースに 満足している

Q7この歩道からの横断は安全である

Q8この歩道は混雑していない

Q9この歩道から横断する場合に待つ必要がない

Q10この歩道は横断するのに便利である

Q11この歩道の幅は広い

Q12この歩道には違法駐車がない

Q13この歩道には店舗の看板や椅子などの障害物が ない

Q14 この歩道にはバリアフリー設備が整っている

Q15この歩道にはベンチなどの休憩場所がある

Q16この歩道の夜間照明は良好である

Q17この歩道は綺麗である（ゴミが落ちていない）

Q18この歩道には雨や日照を避けるスペースがある

Q19この歩道の街路樹には満足している

Q20この歩道に面した商店が多い

Q21この歩道は娛楽施設に面している

Q22 全体的にこの歩道には満足している

\section{A.2 自転車の利用者に対する調查項目}

Q1この自転車道路は安全である

Q2この自転車道路は連続的（直線的）である

Q3 この自転車道路の運転は快適である

Q4この自転車道路を運転することは楽しい

Q5 この自転車道路と車道のストリートスペースに 満足している

Q6この自転車道路と自転車道路のストリートス ペースに満足している
Q7この自転車道路からの横断は安全である

Q8この自転車道路は混雑していない

Q9この自転車道路から横断する場合に待つ必要が ない

Q10この自転車道路は横断するのに便利である

Q11この自転車道路の幅は広い

Q12この自転車道路には違法駐車がない

Q13この自転車道路では満足なスピードを出すこと ができる

Q14この自転車道路の交通標識は適切である

Q15この自転車道路の夜間照明は良好である

Q16この自転車道路は綺麗である（ゴミが落ちてい ない)

Q17この自転車道路には雨や日照を避けるスペース がある

Q18この自転車道路には必要な場所に駐輪場が設置 されている

Q19この自転車道路の駐輪場は安全である（盗難の 心配がない)

Q20この自転車道路の駐輪場の数に満足している

Q21この自転車道路の駐輪場は駅, バス停付近に設 置されている

Q22 全体的にこの自転車道路には満足している

中国では, 横断歩道が少ないことから, 反対側の道路に 移動する場合には, 道路を横断する場合が多い。そのため, いずれの項目においてもQ7, Q9およびQ10では，道路横断 に関する質問が行われている。

\section{補遺2. 適応的指示モデルの概要}

自然科学分野では, 応答（アウトカム）に基づく得点が 行われることが多い，例えば，環境科学の場合には，污染度 を軽度, 中等度, 重度のような分類が行われ, 医学の場合に は，がんの進行程度をステイジ（Stage）により表している. Tian and Tibshirani [1] は, 説明変数に基づく応答変数の得 点化を統計学的に分析する方法として, 適応的指示モデル (AIM ; Adaptive Index Model) を提案している.

いま, $P$ 変数の説明変数べクトル $\boldsymbol{x}=\left(x_{1}, x_{2}, \ldots, x_{P}\right)^{\mathrm{T}}$ が与

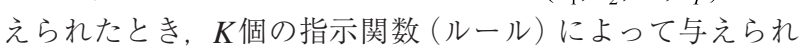
るモデルは,

$$
\eta(\boldsymbol{x})=\beta_{0}+\beta_{1} \sum_{k=1}^{K} I\left(\tilde{x}_{p(k)} \leq c_{p(k)}\right)
$$

である.ここに, $\beta_{j}(j=1,2)$ 個は回帰パラメータ, $\eta(\boldsymbol{x})$ は一般化 線形モデルにおける線形予測子, $I(\cdot)$ は括弧内が真ならば 1 , 偽ならば 0 を与える指示関数, $p(k)$ は $k$ 番目の指示関数で用 いられる変数を表す添え字, $c_{p}(k)$ は $k$ 番目の指示関数のなかで 選択されたカットオフ值である。また，

$$
\tilde{x}_{p(x)}= \begin{cases}x_{p(k)}, & \left(x_{p(k)} \leq c_{p(k)}\right) \text { に対するルール } \\ -x_{p(k)}, & \left(x_{p(k)} \geq c_{p(k)}\right) \text { に対するルール }\end{cases}
$$


である，すなわち，AIM法は，選定された説明変数をカット オフ值を用いてダミー変数に変換し, その総和を用いた単一 変量での一般化線形モデルと捉えることができる

AIM法において, 指示関数 (ルール) の選定は, P個の説 明変数のすべてのカットオフ值の候補（各変数のユニークな 值)に基づいてダミー変数を構成することで探索される。そ して, 回帰パラメータに対するスコア検定統計量が最大にな る変数抢よびカットオフ值が選択される。このとき，ルール に選ばれた変数は, 次回のルールの選択候補から除外され る.ルールの選択は, 最大スコア検定統計量が有意水準 $\alpha$ 未 満になる, あるいは, 予め規定された最大ルール数 $K_{\max }$ にな るまで再帰的に続けられる。

なお, AIM 法は, 統計解析環境 Rのパッケージ aimにおい て実装されている.

\section{謝 辞}

本論文の構成に際し，丁寧な査読を通して貴重なご意見と ご指摘を頂戴した審査員と編集委員の諸先生方に心から深甚 の謝意を表します。

\section{注}

[注 1] 中国政府が公布した，2014年から 2020 年かけての中期計 画である。この計画には, 都市インフラの整備, 環境へ の配慮, 戸籍制度改革, 土地制度改革, 都市の建設管理 体制の整備などが掲げられている [19].

[注2］電気自転車（電気スクーター）とは, モーターを搭載し た電動自転車であり，最高時速は時速 $20 \mathrm{~km}$ 以下である. 中国では，電気自転車は，自転車と同様の非機動車とし て扱われており, 免許不要で使用できる.

[注3] 副省級市とは, 中国の地方自治体の行政区分行政区分の 一つであり，経済，財政および法制の面で省と同程度の 自主権が認められている。中国全土において，15都市が 副省級市に選ばれている。

\section{参 考 文 献}

[1] Tian, L., and Tibshirani, R.: Adaptive index model for marker-based risk stratification, Biostatistics, 12(1), pp. 6886, 2011.

［2］富田健蔵：中国政府の推進する「新型都市化政策」について, 日本不動産学会誌, 28(2), pp.31-37, 2014.

［3］細川政弘, 窪田陽一：街路の景観評価に関する基礎的研究, 土木学会年次学術講演会講演概要集 第 4 部, 32, pp.422423, 1977.

４4］窪田陽一：街路景観の類型に関する構造分析, 日本都市計 画学会学術研究発表会論文集, 18, pp.331-336, 1983.
［5］楊鶤，李力，下川敏雄，北村眞一：成都市における街路景 観の認知構造に関する研究, 日本感性工学会論文誌, 11(2), pp.131-139, 2012

６］楊鶤，李力，下川敏雄，北村眞一：街路景観評価に対する 影響要因の探索：成都市における街路景観の認知構造に関 する研究その 2 , 日本感性工学会論文誌, 11(1), pp.27-37, 2012.

[7] De'ath, G.: Multivariate regression trees: a new technique for constrained classification analysis, Ecology, 83(4), pp.1103-1117, 2002.

[8] Friedman, J.H: Multivariate adaptive regression splines (with discussion), Annals of Statistics, 19(1), pp.1-167, 1991.

[9］山田晴利, 篠原修, 天野光一, 岡田一天：モンタージュに よる街路景観の対高架構造物寛容度に関する研究, 土木計 画学研究·論文集, 1, pp.187-194, 1984.

[10］天野光三，榊原和彦，藤墳忠司：街路空間の心理的効果に ついて, 道路, 420, pp.25-32, 1976.

[11] 北村眞一：空間認知の解析手法の有効性, 都市計画, 138, pp.46-58, 1985.

[12］篠原修，屋代雅充：街路景観のまとまりに及ぼす沿道建物 の効果に関する計量心理学的研究，土木学会論文集，353, IV2, pp.131-138, 1985.

[13] Li, L., Kun, Y., Shimokawa, T., Oyama, I., and Kitamura, S.: Investigation of factors affecting the evaluation of streetscape in Japan and China, International Journal of Affective Engineering, 12(1), pp.1-10, 2013.

[14] Breiman, L.: Random forests, Machine Learning, 45(1), pp.5-32, 2001.

[15] 李力, 下川敏雄, 楊鿂, 黒木学, 大山勲, 北村眞一：日本 および中国での身近な街路景観の認知特性に対する物理的 要因評価：東京 23 区と成都市の国際比較, 日本感性工学 会論文誌, 12(3), pp.369-378, 2013.

[16] Hothorn, T., Hornik, K., and Zeileis, A.: Unbiased recursive partitioning: a conditional inference framework, Journal of Computational and Graphical Statistics, 15(3), pp.651-674, 2006

[17] 中山昂彦, 宮川愛由, 谷口綾子, 井料美帆, 小嶋文, 藤井聡 : 道路空間デザインが歩行者コミュニケーションに及ぼす 影響に関する研究, 交通苦学論文集, 3(4), pp.84-91, 2017.

[18］山本坬人, 嘉名光一, 佐久間康富：低層部が形成する街路 景観の印象評価に関する研究：大阪市御堂筋の沿道建築物 を対象にして，日本建築学会計画系論文集，80, pp.661668, 2015 .

[19（一財）自治体国際化協会北京事務所：中国が取り組む人間 中心の「新都市化」政策，一般財団法人 自治体国際化協会 Clair Report, 424, 2015. 


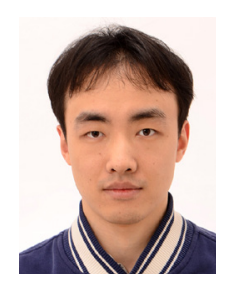

\section{万 可 (非会員)}

2016 年 山梨大学大学院医学工学総合教育部 修士課程 (土木環境工学専攻) 修了. 現在, 北海道大学情報科学研究科博士課程 (情報理 工学) 在学中, 感性工学㧍よび医学における データサイエンスに関する研究を行っている.

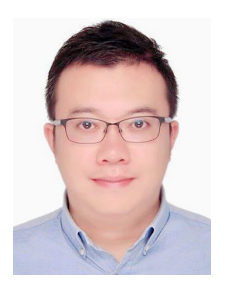

楊 鿂 (非会員)

2012 年 山梨大学大学院医学工学総合教育部 環境社会創生工学専攻博士課程修了. 博士 (工 学). 現在, 中国西南交通大学交通運輸㧍よび 物流学院副教授, および和歌山県立医科大学 医学部博士研究員. 中国成都市 軌道集団 TOD 開発顧問. この間, 物流合理化と港湾整備, 貿易および交通 施設計画, 成都市街路景観分類などの研究を行い, 鉄道道路環境 評価, 成都市濱江路景観設計. 成都市北駅, 南駅TOD開発など の計画設計の実務を行った。

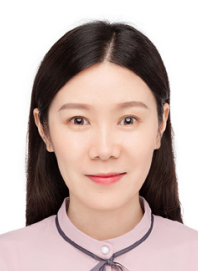

李 力 (非会員)

2013年 山梨大学大学院医学工学総合教育部環 境社会創生工学専攻博士課程修了. 博士.工学). 現在, 中国西南交通大学交通運輸・物流学院 講師. 交通計画·都市景観に関する研究に従事. 2014 年に伝統的街路景観の研究で日本造園学 会 (関東支部) 研究発表賞を受賞.

\section{南 弘征 (非会員)}

1994 年 北海道大学大学院工学研究科情報工学専攻博士後期課程 修了. 博士 (工学). 現在, 北海道大学情報基盤センター教授. 計算機統計学, 情報科学, サイバーセキュリテイに関する研究 に従事. 日本計算機統計学会において理事, 評議員を歴任し, 2019年より監事.

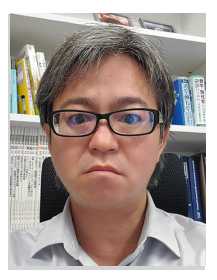

\section{下川 敏雄 (正会員)}

2004年 大阪大学大学院基礎工学研究科修了. 和歌山県立医科大学医学部教授. 大阪大学大 学院医学系研究科招聘教授, 四川大学華西 公共衛生学院講座教授 (中国). 博士 (工学). この間, 医学統計学, 統計教育に関する研究 に従事. その間に, 日本計算機統計学会奨励賞・論文賞・貢献賞, 日本応用統計学会奨励論文賞, 日本感性工学会事例研究賞, 日本 行動計量学会優秀賞を受賞, 2019年〜日本計算機統計学会渉外 理事㧍よび評議員等を歴任.

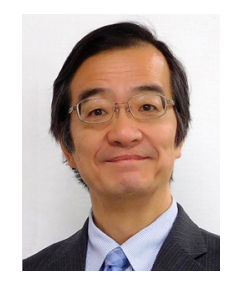

水田 正弘（非会員）

1986 年 北海道大学大学院工学研究科情報工学 専攻博士後期課程修了. 博士 (工学). 北海道 大学情報基盤センター教授. データサイエンス, 計算機統計学, 放射線治療に関する研究に 従事. 応用統計学会において評議員, 副会長, 日本計算機統計学会において評議員, 副会長, 会長, IASC (国際計 算機統計学会) Council Member 歴任. 